\title{
Exergoeconomic and exergoenvironmental analysis of the evacuated tube heat pipe; a experimental study
}

\author{
Arif Karabuga ${ }^{1 *}$, Melik Ziya Yakut ${ }^{2}$, Zafer Utlu $^{3}$ \\ ${ }^{1 *}$ Sustainable Energy Systems Application and Research Center, Haliç University, 34445, Istanbul, Turkey \\ ${ }^{2}$ Mechatronics Engineering, Faculty of Technology, Isparta University of Applied Sciences, 32200, Isparta, Turkey \\ ${ }^{3}$ Faculty of Engineering, Mechanical Engineering, Haliç University, 34445, Istanbul, Turkey \\ E-mail: arifkarabuga@halic.edu.tr
}

Received 10 February 2021, Revised 16 April 2021, Accepted 15 May 2021

\begin{abstract}
In this paper, the thermodynamic performance of a boroxide-added glass evacuated tube heat pipe (ETHP) is studied, including energy, exergy, environmental, economic analysis, and sustainability index. It has been found that $50,87 \%$ of the energy loss of water and 50,86\% of the exergy loss of water are caused by radiation. There are 4 collectors each collector 57 pipes as a total of 108 pieces pipes, a hot water tank, a heat exchanger, and a pump in the system. The water is used as a working fluid due to economic and common use in the system. In the result of this experimental study, we calculated energy and exergy efficiencies of the EHTP system as \% 22,21 and \% 13,68, respectively. In addition, the environmental, exergoenviromental, enviroeconomic, and exergoenviroeconomic values of the EHTP system are found $458,5 \mathrm{kgCO}_{2} /$ day, $456,5 \mathrm{kgCO}_{2} /$ day, $0,003708 \$ /$ day and $0.003692 \$ /$ day, respectively. Also, the sustainability index of the system is found as 1,159 .
\end{abstract}

Keywords: Solar energy; Exergy analysis; Evacuated tube heat pipe collector; Sustainability

\section{Introduction}

Due to the releases of $\mathrm{CO}_{2}$ and other gases during volcanic activities, solar radiation, and the burning of fossil fuels, the temperature of the earth increases significantly. Volcanic activities and solar radiation are natural phenomena that cannot be avoided. On the contrary, the emissions that occur due to the use of fossil fuels are anthropological. In other words, it can be prevented, unlike the other two reasons. The greatest power we have to prevent global warming is to prevent anthropological emissions. The causes and results of global warming are illustrated in Fig. 1. The energy source that stands out as an alternative to fossil fuels is solar energy because it is both economical and environmentally friendly [1].

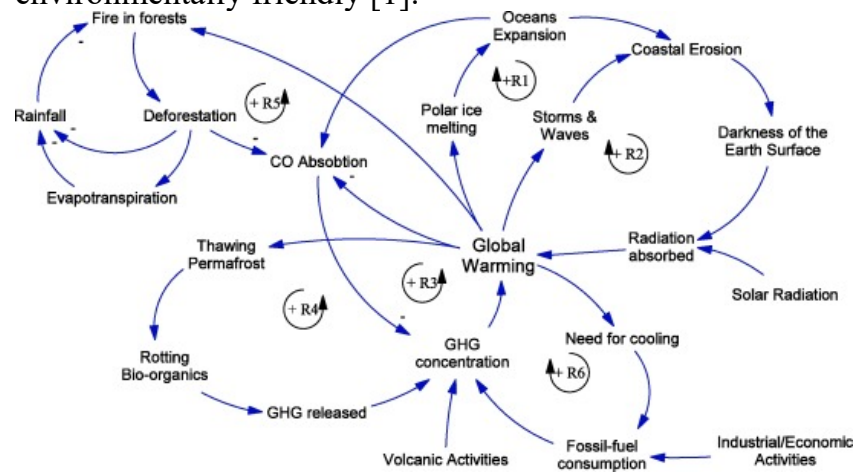

Figure 1. Causes and results of the global warming [1]

There are three methods such as direct electrical production, thermal energy generation, and passive usage for solar energy use. The most important component in thermal power generation is the solar collector that transfers the radiation from the sun to heat transfer [2, 3]. There are different kinds of solar collectors. Also, in general, collectors separate the two variety as concentrate, and flat-plate collectors [4]. This study examines the ETHP solar collector, a type of solar collector with a flat plate. The ETHP is a flat plate type of solar collector that is known to have a higher thermal efficiency than the flat plate solar collector due to the vacuum that exists between the absorber glass pipe and the outside glass. Due to this vacuum zone reduces the heat losses from the collector by convection and conduction. As a result, it enables the working fluid to be obtained at higher outlet temperatures. Since heat losses in vacuum pipes are negligible, it has a significant advantage, such as higher efficiency compared to flat plate collectors. $[5,6]$.

In the literature, there are several studies dealing the thermodynamic performance analysis of ETHP systems. Some of these studies focus on the solar drying, thermal storage, hot water production for domestic usage, fresh water, and multigenerational systems. Lamnatou et al. [7] have evaluated the thermodynamic analysis of a solar drying system using a vacuum tube collector. The parameters affecting the efficiency in the collector based on the drying of agricultural products are examined. It has been calculated that the collector efficiency varies between $50-60 \%$ at different air flow rates and radiation intensities. Modi and Pandya [8] investigated the adsorption cooling system integrated into the vacuum tube collector. AC35 / methanol is used in the adsorption 
cooling system. Obtaining ice from the cooling system has been adopted as the main criterion. It was found that the radiation intensity should be $800 \mathrm{~W} / \mathrm{m}^{2}$ for ice production. It was calculated that 12.82 tons of $\mathrm{CO}_{2}$ emission were prevented from meeting the energy required in the cooling system from the evacuated tube collector. Saxena and Gaur [9] have presented a 3E (energy, exergy and economical) analysis of a vacuum tube solar collector. Heat exchanger and water heating system are integrated into the collector. In the study, two vacuum tube pipes were used experimentally. $\mathrm{CuO}$ nanofluid and water were used as working fluid. When using $\mathrm{CuO}$ nanofluid, maximum energy and exergy efficiency were calculated as $45.12 \%$ and $9.51 \%$, respectively. Kumar et. al. [10] studied the thermal performance of a vacuum tube solar collector. In their study, they focused on heating the air with the collector. Performance measurements are made at different air flow rates, such that the lowest efficiency of the system is measured at $42.8 \mathrm{C}$ temperature and $100 \mathrm{~kg} / \mathrm{h}$ flow rate. The system's maximum it's effective thermal efficiency is calculated as $48.47 \%$ at $400 \mathrm{~kg} / \mathrm{h}$ flow rate. Olfian et. al. [11] presented the thermal performance of the phase change material integrated evacuated tube solar collector, So that the assessment of the charge and discharge process of the phase change material. They used Ushaped evacuated tube in the solar collector. The thermal efficiency of the collector is calculated to vary between $22.96 \%$ and $27.91 \%$ under different conditions. Ozsoy and Corumlu [12] analyzed the thermal performance of an evacuated tube solar collector using Silver-Water nanofluid. In the study conducted under laboratory conditions, sunlight was simulated. In the thermosyphon heat pipe, pure water and nanofluid were compared, such that an increase in efficiency of $20-40 \%$ was measured in the nanofluid system. Corumlu et. al. [13] evaluated the thermodynamic analysis of the evacuated tube solar collector for hydrogen production system. The evacuated tube solar collector is used for the required water temperature in the PEM electrolyzer. The electrical energy required for PEM is supplied directly from the photovoltaic system that generates electricity. The presented study consists of four subsystems, so the efficiency of all subsystems was evaluated separately. The exergy efficiency of the solar collector has been calculated as $27.35 \%$. Kizilkan et. al. [14] evaluated the thermodynamic analysis of power and heat generation from an evacuated tube solar collector. Transcritical $\mathrm{CO}_{2}$ fluid Rankine cycle was integrated power generation. A total of 19 solar collectors were used in the system. The efficiency of the whole system was calculated as $28.3 \%$ in the summer season, which was the highest.

The main purpose of the study is to perform optimizations in order to achieve the best performance in terms of efficiency, environmental and economy of the system. In addition, parametric analyzes will be made to evaluate important parameters in the system. The detailed objectives of this proposed study are given below;

- Evaluation of an ETHP solar collector used in the application with a combination of energy, exergy, environmental and economic perspective

- To analyze exergoenviromental which is an exergy based environmental assessment
- To analyze exergoenviroeconomic which is an exergy based economic evaluation

- To assess the sustainability index and entropy generation rate of the ETHP system

- To determine the exergy efficiency and the exergy destruction rate of ETHP system

The novelty of the study is to provide solutions and evaluations in real commercial applications by determining the energy, environmental and economic performance parameters of the ETHP system, which is used to meet the domestic needs of a 9-floor building.

\section{Experimental Setup}

As a case study, the evacuated tube heat pipe is chosen to assess a solar system by using the exergy, environmental, exergoenviromental, enviroeconomic, and exergoenviroeconomic analyses. The investigated system is shown in Figure 1. Systems with light structures and lowcost technology for process heat applications to medium temperature could be obtained with ETHP solar collector [15]. ETHP is considered as an exchanger because it converts sunlight energy into thermal energy. ETHP systems are suitable to produce clean water and cogeneration systems by adding the necessary equipment [16-21]. The ETHP solar collector consists of 108 evacuated tubes and hot tank as shown in Figure 1. Due to its many advantages such as economical, eco-friendly, and the structure of the plumbing in the building where the application, water has been utilized as a working fluid. Also, there is one heat exchanger in the system. This heat exchanger has been used to transfer the heat energy of the working fluid to the plumbing used in domestic use. The pipes used in the ETHP system consist of two intertwined glass pipes. There is a vacuum between the pipes. The picture of the pipe is given in Figure 2. In addition, technical details of the pipes are presented in Table 1. The ETHP system other components such as heat exchanger and circle pump as shown in Figure 3.

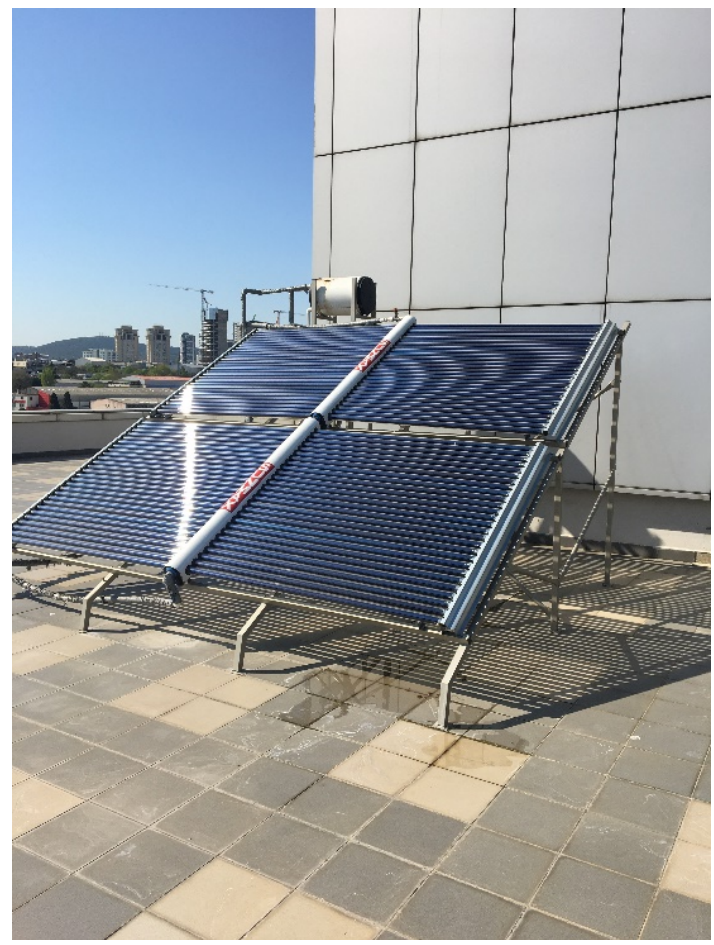

Figure 1. ETHP solar collector 


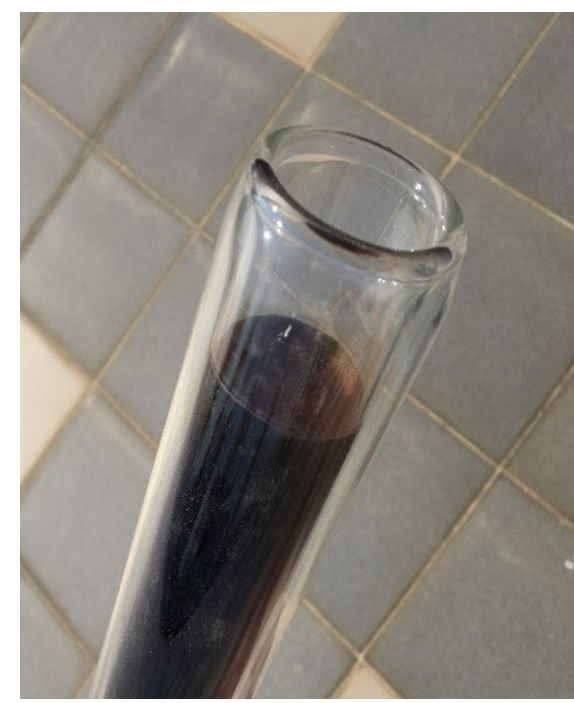

(a)

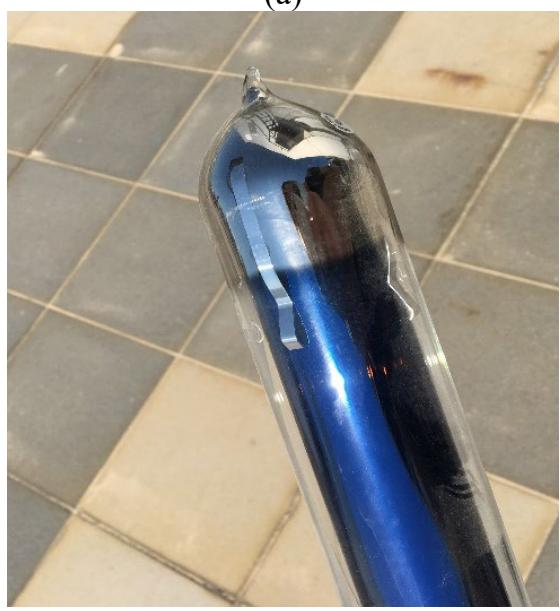

(b)

Figure 2. Evacuated tube used in the system

The evacuated tubes used in the study were produced by intertwining two glass pipes and vacuuming the air in between. There are various coatings such that, these are copper, aluminum nitrate and black selective coating on the inner tube. The tubes used are made of boroxide-added glass to withstand high-temperature changes.

Table 1. Design Parameters of the ETHP system

\begin{tabular}{ll}
\hline Dimension & Value \\
\hline Glass tube outer diameter & $47 \mathrm{~mm}$ \\
Glass tube inner diameter & $38 \mathrm{~mm}$ \\
Glass thickness & $1 \mathrm{~mm}$ \\
Length of the evacuated tube & $1800 \mathrm{~mm}$ \\
Number of evacuated tube & 108 pieces \\
Number of collector & 4 pieces \\
Collector tilt angle & $42^{\circ}$ \\
Solar irradiation & $550 \mathrm{~W} / \mathrm{m}^{2}$ \\
Collector aperture area & $23,22 \mathrm{~m}{ }^{2}$ \\
Emissivity receiver & 0,95 \\
Emissivity glass cover & 0,88 \\
$\mathrm{CO}_{2}$ emission value & $6,47 \mathrm{xe}^{-6} \mathrm{kgCO}_{2} / \mathrm{Wh}$ \\
Carbone price & $0,0145 \$ / \mathrm{kgCO}_{2}$ \\
\hline
\end{tabular}

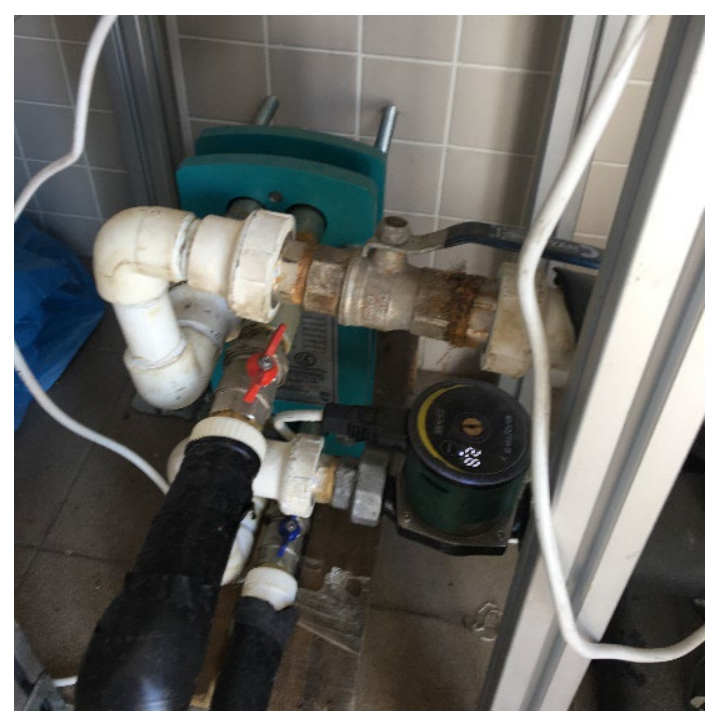

Figure 3. The other components of the ETHP system

\section{Thermodynamic Analysis}

This section was investigated the thermodynamic behavior of the system. However to determine the thermodynamic performance the respective calculations are performed for the inlet and outlet enthalpy, exergy, mass flow rate, solar radiation, energy loss, and exergy loss. For the calculation of these equations, the Engineering Equation Solver (EES) program is used for parametric studies and graphical drawings. To catalyze the complexity involved in the thermodynamic analysis some assumptions are made as follows;

- The system operates under a steady-stead condition

- In the system, the changes in the kinetic and potential energies can be disregarded

- The system is considered a control volume

- Pressure drop at the end of the tube is negligible

- Temperature loss at the hot storage is negligible

- Pressure drop at the connecting pipes and fittings is negligible

- Solar insolation absorbed by the inner glass is uniformly distributed throughout the length and protect uniform temperature

The operation temperature and pressure values are presented in Table 2.

Table 2. Operation parameters of ETHP system

\begin{tabular}{lc}
\hline \multicolumn{1}{c}{ Parameter } & Value \\
\hline Collector input temperature & $23^{\circ} \mathrm{C}$ \\
Collector input pressure & $2,3 \mathrm{bar}$ \\
\hline Collector output temperature & $88^{\circ} \mathrm{C}$ \\
Collector output pressure & $2,3 \mathrm{bar}$ \\
\hline Heat exchanger output temperature & $21,5^{\circ} \mathrm{C}$ \\
Pump input pressure & $2,3 \mathrm{bar}$ \\
\hline
\end{tabular}

Based on the assumptions the energy change of the water equation for the ETHP system are written as follows [22];

$\dot{E} n_{\text {water }}=\dot{m} c_{p}\left(T_{\text {out }}-T_{\text {in }}\right)$ 
Where $\dot{m}, c_{p}, T_{\text {out }}$ and $T_{\text {in }}$ are mass flow of water, specific heat of water, temperature of output water and temperature of input water, respectively.

$\dot{E n_{\text {solar }}}=I \rho_{\text {ref }} \rho_{\text {rec }} \varepsilon_{\text {rec }} A_{n} A_{\text {rec }}$

Where $I, \rho_{\text {ref }}, \rho_{\text {rec }}, \varepsilon_{\text {rec }}, A_{\text {rec }}, A_{n}$ are solar radiation, reflectance of the receiver, absorber of the receiver, emissivity of the receiver, receiver area, and receiver numbers, respectively. The exergy change of the water in ETHP system is calculated by following [23];

$\dot{E} x_{\text {water }}=\dot{E} x_{\text {out }}-\dot{E} x_{\text {in }}$

Where $\dot{E} x_{\text {out }}$ and $\dot{E} x_{\text {in }}$ are exergy of the output water and exergy of the input water, respectively [24]

$\dot{E} x_{\text {out }}=\dot{m} c_{p}\left[\left(T_{\text {out }}-T_{\text {air }}\right)-T_{\text {air }}\left(\ln \left(\frac{T_{\text {out }}}{T_{\text {air }}}\right)\right)\right]$

$\dot{E} x_{\text {in }}=\dot{m} c_{p}\left[\left(T_{\text {in }}-T_{\text {air }}\right)-T_{\text {air }}\left(\ln \left(\frac{T_{\text {in }}}{T_{\text {air }}}\right)\right)\right]$

Where $\dot{m}, c_{p}, T_{\text {out }}, T_{\text {air }}$, and $T_{\text {in }}$ are mass flow, specific heat, temperature of the output water, ambient temperature, temperature of the input water. Input solar radiation exergy rate is found by following [24];

$\dot{E} x_{\text {solar }}=\dot{E n_{\text {solar }}}\left(1+\frac{1}{3}\left(\frac{T_{\text {air }}}{T_{\text {sun }}}\right)^{4}-\frac{4}{3}\left(\frac{T_{\text {air }}}{T_{\text {sun }}}\right)\right)$

Where $T_{\text {sun }}$ is solar temperature. Exergy efficiency of ETHP system is calculated by following [25];

$\eta_{I I}=\frac{\dot{E} x_{\text {water }}}{\dot{E x_{\text {solar }}}}$

Sustainability analysis is applied using the sustainability index method for various thermodynamic applies. This process explains how exergy efficiency affects the sustainability of the resources [26]. The sustainability index can be found in the following equation [27];

$S I=\frac{1}{1-\eta_{I I}}$

The energy loss in the system is due to convection and radiation. Total energy loss is found by [22];

$\dot{E} n_{\text {loss }}=\dot{E} n_{\text {loss,conv }}+\dot{E} n_{\text {loss }, \mathrm{rad}}$

Where $\dot{E} n_{\text {loss,conv }}$ and $\dot{E} n_{\text {loss,rad }}$ are energy loss with convection and radiation, respectively [28].

$\dot{E n_{\text {loss }, \text { conv }}}=h A_{\text {gs }}\left(T_{\text {surf }}-T_{\text {air }}\right)$

Where $h, A_{\text {gs }}$ and $T_{\text {surf }}$ are heat transfer coefficient, heat transfer surface area of glass cover and the glass cover surface temperature, respectively [14].

$h=\frac{k N u}{L}$

Where $k$ nd $D$ ra e th ermal co nductivity an $\mathrm{d}$ characteristic length, respectively [14].
$N u=0,4+0,54 R e^{0,52}$ for $0,1<R e \leq 1000$

$N u=0,3 R e^{0,6}$ for $1000<R e \leq 50000$

Where $R e$ is Reynolds number. Energy loss with the radiation is found by [29];

$\dot{E n_{\text {loss }, \text { rad }}}=\varepsilon \sigma A_{\text {gs }}\left(T_{\text {surf }}^{4}-T_{\text {sky }}^{4}\right)$

Where $\varepsilon, \sigma$ and $T_{s k y}$ are emissivity, Stefan-Boltzmann constant and sky temperature, respectively.

Exergy loss is as energy loss and total exergy loss is found by [24];

$\dot{E} x_{l o s s}=\dot{E} x_{l o s s, c o n v}+\dot{E} x_{l o s s, r a d}$

Where $\dot{E} x_{\text {loss,conv }}$ and $\dot{E} x_{\text {loss,rad }}$ are exergy loss with convection and radiation, respectively [25].

$$
\begin{aligned}
& \dot{E} x_{\text {loss }, \mathrm{conv}}=\dot{E} n_{\text {loss }, \mathrm{conv}}\left(1-\frac{T_{\text {air }}}{T_{\text {surf }}}\right) \\
& \dot{E} x_{\text {loss }, \text { rad }}=\dot{E n_{\text {loss }, \text { rad }}}\left(1-\frac{T_{\text {air }}}{T_{\text {surf }}}\right)
\end{aligned}
$$

The exergy destruction rate of the collector can be found in the following equation [32];

$\dot{E} x_{\text {dest }}=\dot{E} x_{\text {in }}+\dot{E} x_{\text {solar }}-\dot{E} x_{\text {out }}-\dot{E} x_{\text {loss }}$

The exergy destruction rate of the heat exchanger can be found in the following equation [32];

$$
\begin{aligned}
& \dot{E} x_{\text {in,sys }}+\dot{E} x_{\text {in }, \text { refrigerant }}=\dot{E} x_{\text {out }, \text { sys }}+ \\
& \dot{E} x_{\text {out }, \text { refrigerant }}+\dot{E} x_{\text {dest }, H E}
\end{aligned}
$$

The use of fossil fuels to produce energy to domestic will result in harmful gas emissions. Using a solar collector system can cut back that problem. Considering the environmental problems caused from energy consumption, such as greenhouse gases, the importance of environmental analysis appeared more than before. The environmental analysis of the system can be found in the following equation [33];

$x_{\mathrm{CO} 2}=y_{\mathrm{CO} 2} \dot{E n}_{\text {solar }} t_{\text {working }}$

Where $y_{\mathrm{CO} 2}$ and $t_{\text {working }}$ are carbon dioxide emission value and working hours of the system. The Enviroeconomic analysis is based on the amount of $\mathrm{CO} 2$ decrease from the thermodynamic process and carbon credit earned importance. Establishing renewable energy-based energy production systems prevents / reduces harmful emissions [33]. The enviroeconomic analysis of the system can be found in the following equation [22];

$E c_{\mathrm{CO} 2}=x_{\mathrm{CO} 2} c_{\mathrm{CO} 2}$

Where $c_{\mathrm{CO} 2}$ is carbon dioxide price. An exergoenvironmental analysis is focused on three steps. The first step is an exergy analysis of the ETHP system. In the second step, environmental effects are assessed by a life 
cycle analysis method. In the three steps, the environmental effects are applied to the exergy stream of the ETHP system. Exergy-based environment impact value called, environmental impact rate associated with exergy. Means of this; an input environmental impact has an alternative action with the output thermodynamic relations [34]. The exergoenvironmental analysis of the system can be found in the following equation [22];

$x_{\text {exCO2 }}=y_{\mathrm{CO} 2} E x_{\text {solar }} t_{\text {working }}$

Exergoeconomic (thermoeconomic) is an approach of engineering that unite the second law of the thermodynamic economic principles; thence, this provides information that is not available through conventional thermodynamic analysis, and economic research for the engineerings [35]. Moreover, an exergoeconomic analysis reveals the origin, magnitude and location of cost of thermodynamic inefficiencies in energy conversion systems. The exergoenviroeconomic analysis of the system can be found in the following equation [22];

$E c_{\text {exCO2 }}=x_{\text {exCO2 }} c_{\mathrm{CO} 2}$

\subsection{Uncertainty analysis}

Uncertainty analysis is needed to prove the accuracy of the experiments [36]. Irradiance measurement was done with solar flow received by unit area, expressed in $\mathrm{W} / \mathrm{m}$. Solarimeter is having a sensitivity of $\pm 5 \%$. The temperature measurement was done by $\mathrm{K}$ type thermocouples calibrated by the accuracy of $\pm 1,1^{\circ} \mathrm{C}$. The pressure change was measured with an accuracy of \pm 2 mbar. The uncertainty analysis of the system can be found in the following equation [37];

$\frac{\partial R}{R}=\left[\left(\frac{\partial R}{\partial x_{1}} \delta x_{1}\right)+\left(\frac{\partial R}{\partial x_{2}} \delta x_{2}\right)+\left(\frac{\partial R}{\partial x_{3}} \delta x_{3}\right)+\ldots \ldots+\left(\frac{\partial R}{\partial x_{k}} \delta x_{k}\right)\right]^{\frac{1}{2}}$

Where, $\partial R$ is determined as absolute uncertainty, morever $\frac{\partial R}{R}$ is determined as relative uncertainty. $\delta x_{k}$ is possible errors in $\partial x_{k}$.

\section{Results and Discussion}

In this section, the analysis results of the investigated ETHP system are presented. Furthermore, parametric analyses are performed for the investigation of the effective ambient temperature and solar radiation on the evacuated solar collector performance. The energy efficiency analysis isn't enough to decide how efficiently the system works in engineering applications or designs, only exergy efficiency is offered instead of energy efficiency.

The calculated average uncertainty of the presented system is shown in table 3 .

Tabel 3. Uncertainty analysis results of the parameters

\begin{tabular}{lcc}
\hline \multicolumn{1}{c}{ Parameter } & $\begin{array}{c}\text { Nominal } \\
\text { value }\end{array}$ & Uncertainty rate \\
\hline $\begin{array}{l}\text { Irradiance } \\
\text { Collector inlet } \\
\text { temperature }\end{array}$ & $550 \mathrm{~W}$ & $\pm 0,05$ \\
$\begin{array}{l}\text { Collector outlet } \\
\text { temperature }\end{array}$ & $23^{\circ} \mathrm{C}$ & $\pm 1,1^{\circ} \mathrm{C}$ \\
& $88^{\circ} \mathrm{C}$ & $\pm 1,1^{\circ} \mathrm{C}$
\end{tabular}

Collector inlet

pressure

Collector outlet

pressure

2,3 bar

$\pm 0,002$ bar

Heat exchanger

inlet temperature

$25^{\circ} \mathrm{C}$

$\pm 1,1^{\circ} \mathrm{C}$

(feedwater)

Heat exchanger

outlet temperature

$68^{\circ} \mathrm{C}$

$\pm 1,1^{\circ} \mathrm{C}$

Heat exchanger

inlet pressure

Heat exchanger

outlet pressure

Pump inlet

temperature

Pump inlet

pressure

1 bar

$\pm 0,002$ bar

1 bar

$\pm 0,002$ bar

Total system

$$
21,5^{\circ} \mathrm{C} \quad \pm 1,1{ }^{\circ} \mathrm{C}
$$

2,3 bar $\quad \pm 0,002$ bar

$\pm 0,034$

The Rayleigh (Ra) number is calculated as $3,749 \mathrm{e}^{7}$ in order to find the Nusselt $(\mathrm{Nu})$ number value, which is the critical value in the heat loss analysis of the absorber pipe. The thermodynamic results obtained as a result of the calculations made are given in Table 4.

Table 4. Thermodynamic results of the ETHP system

\begin{tabular}{|c|c|c|}
\hline Parameter & Value & Unit \\
\hline$\dot{E} n_{\text {solar }}$ & 3953 & $W$ \\
\hline$E n_{\text {water }}$ & 877,8 & $W$ \\
\hline$\dot{E} n_{\text {loss }}$ & 765,4 & $W$ \\
\hline$E n_{\text {loss }, \text { rad }}$ & 389,4 & $W$ \\
\hline$x_{\text {CO2 }}$ & 458,5 & $\mathrm{kgCO} /$ day \\
\hline$E c_{\text {CO2 }}$ & 0.003708 & $\$ /$ day \\
\hline$E x_{\text {solar }}$ & 3734 & $W$ \\
\hline$\dot{E} x_{\text {water }}$ & 538,5 & $W$ \\
\hline$\dot{E} x_{\text {loss }}$ & 722,7 & $W$ \\
\hline$\dot{E} x_{\text {loss }, \text { rad }}$ & 367,6 & $W$ \\
\hline$\eta_{\text {system }}$ & 22,21 & $\%$ \\
\hline$\psi_{\text {system }}$ & 13,68 & $\%$ \\
\hline SI & 1,159 & - \\
\hline$x_{\text {exco2 }}$ & 456,5 & $\mathrm{kgCO} /$ day \\
\hline$E c_{\text {exco } 2}$ & 0,003692 & $\$ /$ day \\
\hline
\end{tabular}

The results of the energy-based analysis of the ETHP system, which are the solar energy input, energy of the water energy loss, energy radiation loss, environmental analysis and enviroeconomic analysis values are calculated as 3953 $\mathrm{W}, 877,8 \mathrm{~W}, 765,4 \mathrm{~W}, 389,4 \mathrm{~W}, 458,5 \quad \mathrm{kgCO}_{2} /$ day and $0,003708 \$$ /day, respectively. Furthermore, the results of the exergy-based analysis of the ETHP system, which are the solar exergy input, exergy of the water, exergy loss, exergy radiation loss, exergoenvironmental analysis and exergoenviroeconomic analysis values are calculated as $33734 \mathrm{~W}, 538,5 \mathrm{~W}, 722,7 \mathrm{~W}, 367,6 \mathrm{~W}, 456,5 \mathrm{kgCO} 2 /$ day and $0.003692 \$ /$ day, respectively. In additional, the energy, exergy efficiency and sustainability index of the ETHP system are found as $22,21 \%, 13,68 \%$ and 1,159 , respectively. Otherwise, the performance analysis of the ETHP system, a comparative parametric study is also carried out in order to determine the effect of solar radiation intensity of the energy and exergy efficient. The radiation intensity 
variation with ETHP system thermodynamic efficiencies is shown in Figure 4. During this analysis, the mass flow of the working fluid is fixed to a constant amount so that to meet the required heat energy, the required energy and exergy efficiency of the ETHP is calculated. As expected, the exergy efficiency of the ETHP reduces the rise of radiation intensity. Because energy and exergy efficient decrease depending on the exergy destruction of the collector increase. Table 5 shows the exergy destruction rate of ETHP components such as collector, heat exchanger, and pump.

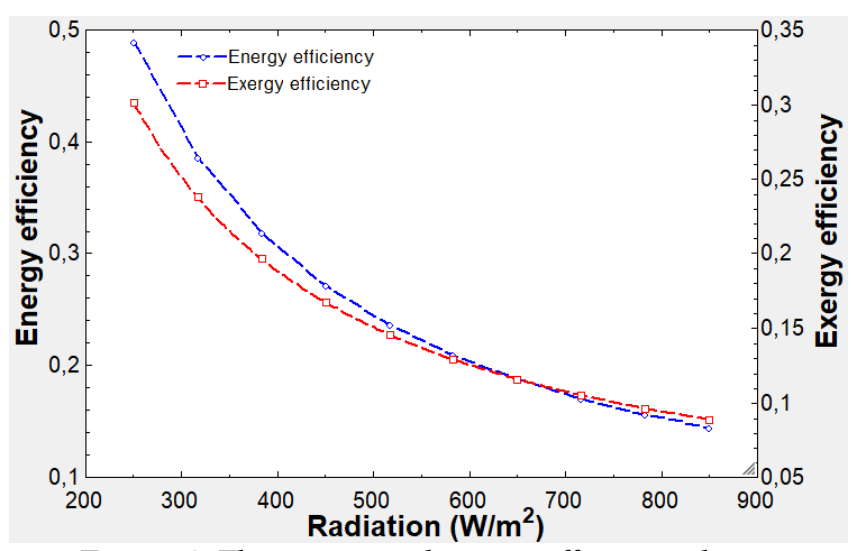

Figure 4. The energy and exergy efficiency change depending on solar radiation

Table 5. Exergy destruction rate of the components

\begin{tabular}{lc}
\hline Component & Exergy destruction value \\
\hline Collector & $2841 \mathrm{~W}$ \\
Heat exchanger & $16,7 \mathrm{~W}$ \\
Pump & $17,42 \mathrm{~W}$ \\
\hline
\end{tabular}

The highest exergy destruction is calculated in the ETHP solar collector. The exergy destruction of the collector was $2841 \mathrm{~W}$, followed by the circulating pump with $17,42 \mathrm{~W}$. The lowest exergy destruction between components is a heat exchanger as $16,7 \mathrm{~W}$. In solar thermal systems, the ambient temperature has an effect on the system performance, which is normally negative as the ambient temperature increases. The effect of ambient temperature on the performance efficiency is evaluated and offered in Figure 5. In addition, the sustainability index of the system is decreasing, as is the exergy change of the water. The reason for the decrease in the exergy change of water of ETHP is the decrease in both useful energies and, its decrease sustainability index of the system as the ambient temperature increases.

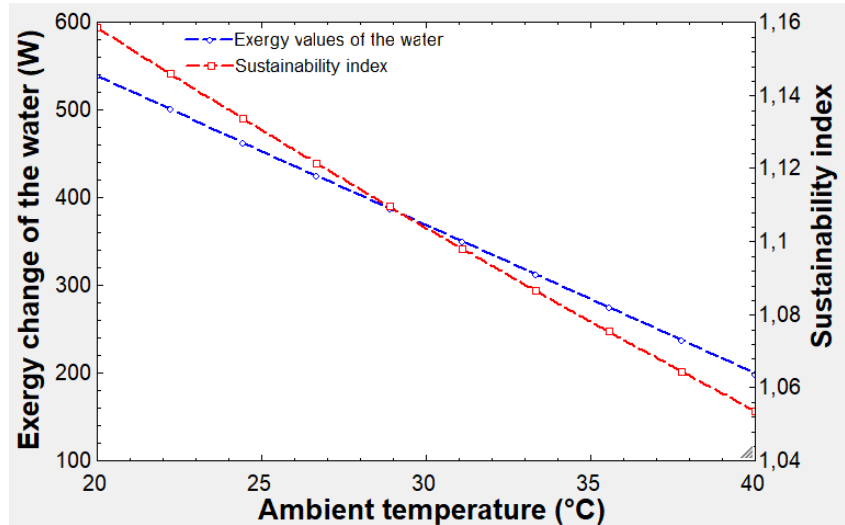

Figure 5. The exergy change of the water and sustainability index change depending on ambient temperature
The best assessment of ETHP can be obtained by examining the performance of the solar collector for different ambient temperatures, such that ambient temperature is one of the effective parameters in the second law of thermodynamics. The analysis has been carried out using the average ambient temperature values of the months for different season conditions. The temperature difference between seasons is approximately $20^{\circ} \mathrm{C}$ due to Turkey is the Mediterranean climatic zone. The exergy change of the water of the ambient temperature of the ETHP system is illustrated. The results show that the amount of exergy change of the water in the collector is the lowest when the ambient temperature is $40^{\circ} \mathrm{C}$ with nearly $200 \mathrm{~W}$. During the seasons with the lowest ambient temperature, the system performance increases, and it has the highest value. This is on account of the fact that, during the summer period, the irreversibility rate reaches of the ETHP system a maximum value. In Figure 6, by changing the collector output temperature from $80^{\circ} \mathrm{C}$ to $150^{\circ} \mathrm{C}$, the exergy destruction of collector and heat exchanger is illustrated.

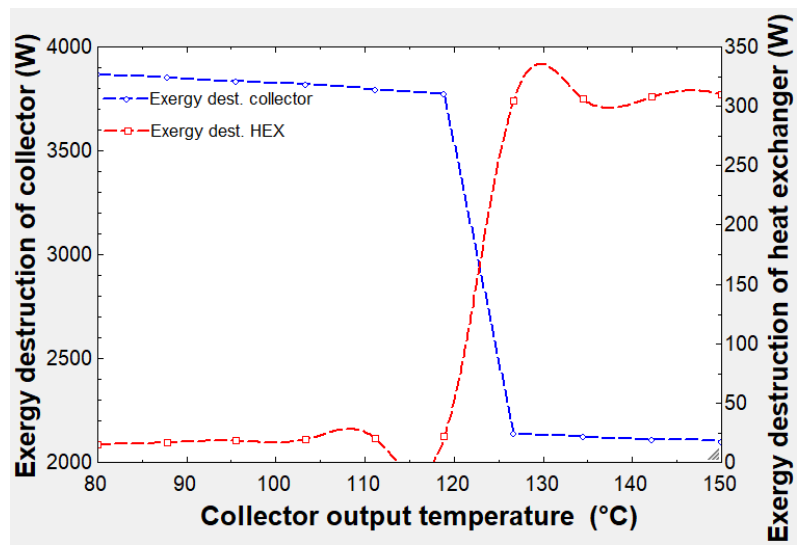

Figure 6. The exergy destruction of the collector and heat exchanger change depending on collector output temperature

As in Figure 6, for the solar system components, in this range of collector output temperature parameters, the exergy destruction of the HEX increases while the exergy destruction of the collector decreases. The cause for this trend is that at the critical temperature of $125^{\circ} \mathrm{C}$, enthalpy increases by $420 \%$ while entropy production increases by $350 \%$. In Figure 7, by changing the solar radiation from 200 $\mathrm{W} / \mathrm{m}^{2}$ to $900 \mathrm{~W} / \mathrm{m}^{2}$, the environmental and exergoenvironmental is illustrated.

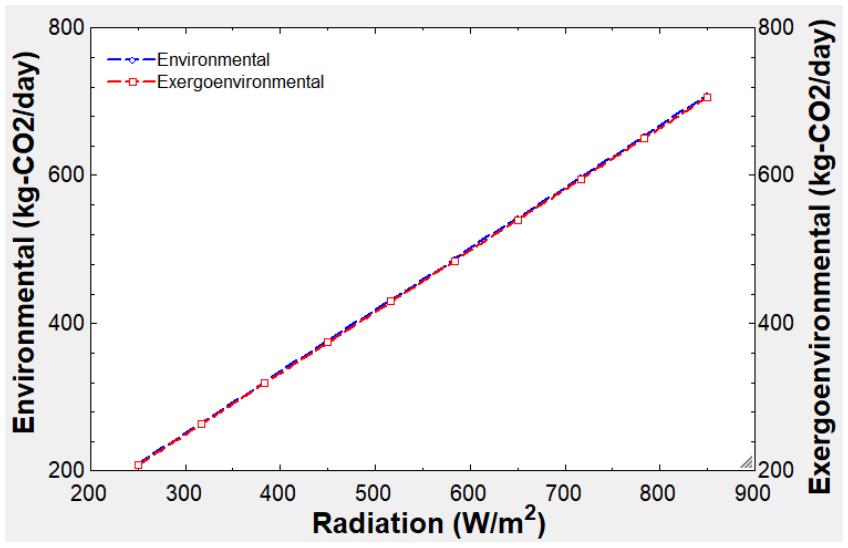

Figure 7. The change of the environmental and exergoenvironmental values depending on solar radiation 
Figure 7 shows the impacts of the varying solar radiation on the environmental and exergoenvironmental of the system. As can be noted from this figure, the environmental effect of the investigated solar system increases from approximately $208,4 \mathrm{~kg}-\mathrm{CO}_{2} /$ day to $708,6 \mathrm{~kg}-\mathrm{CO}_{2} /$ day with the increase in these solar radiation ranges. Similarly, exergoenvironmental effect increases from 207,5 kg$\mathrm{CO}_{2}$ /day to $705,5 \mathrm{~kg}-\mathrm{CO}_{2} /$ day with the increase in these radiation ranges. In Figure 7 , by changing the solar radiation from $250 \mathrm{~W} / \mathrm{m}^{2}$ to $850 \mathrm{~W} / \mathrm{m}^{2}$, the environmental and exergoenvironmental is illustrated. In Figure 8 , by changing the solar radiation from $200 \mathrm{~W} / \mathrm{m}^{2}$ to $900 \mathrm{~W} / \mathrm{m}^{2}$, the enviroeconomic and exergoenviroeconomic is illustrated.

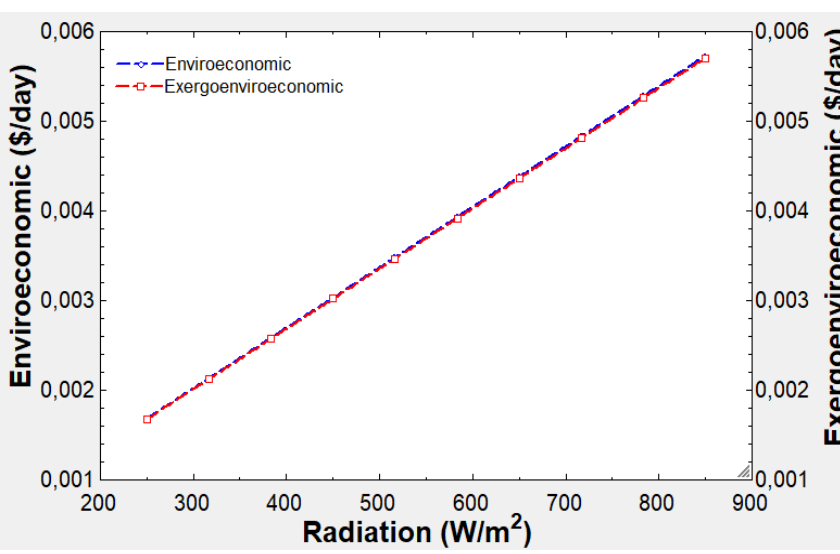

Figure 8. The change of the enviroeconomic and exergoenviroeconomic values depending on solar radiation

Figure 8 shows the impacts of the varying solar radiation on the enviroeconomic and exergoenviroeconomic of the system. As can be noted from this figure, the environmental effect of the investigated solar system increases from approximately $0,001686 \$$ day to $0,005731 \$$ /day with the increase in these solar radiation ranges. Similarly, exergoenvironmental effect increases from 0,001678 \$/day to $0,005706 \$$ day with the increase in these radiation ranges.

\section{Conclusion}

In the presented paper, a model of the thermodynamic analysis of the ETHP system is developed for termoeconomic and exergoenvironmetal. Parametric investigate are so applied to assess the effects of operating parameters on ETHP system performance. The primary results of the present study can be ordered by follows:

- The energy and exergy efficiency of the ETHP system are calculated as $22,21 \%$ and $13,68 \%$, respectively.

- During the analysis, it is found that the most effective parameter on the exergy efficiency is the solar irradiation intensity when the mass flow rate is $2,8 \mathrm{~kg} / \mathrm{s}$ constant.

- Energy-based environmental and thermo-economic analysis of the ETHP system is calculated as 458,5 $\mathrm{kgCO}_{2} /$ day and 0.003708 \$ day, respectively.

- Exergy-based environmental (exergoenviromental) and thermo-economic (exergoenviroeconomic) analysis of the system is calculated as 456,5 $\mathrm{kgCO}_{2} /$ day and $0.003692 \$$ /day, respectively.

- Due to the increase in ambient temperature, it causes a important decrease in both the exergy efficiency and sustainability index of the system.

The results of the study can be beneficial for the novel design of the ETHP and researcher. In addition, flow analysis of the system with CFD analysis will be examined in future studies.

\section{Acknowledgements:}

This work was funded by Scientific Research Projects Unit of Haliç University. Project Number: HBAP604-I-1: Modeling and performance analysis of power generation from evacuated tube heat pipe solar energy collectors. Also, the research collaboration among the institutions and universities of the authors are also grateful.

$\begin{array}{ll}\text { Nomenclature } & \\ \mathrm{A}_{\mathrm{n}} & \text { Pipe number } \\ \mathrm{A}_{\mathrm{rec}} & \text { Receiver area, } \mathrm{m}^{2} \\ \mathrm{C}_{\mathrm{p}} & \text { Spesific heat, } \mathrm{kJ} / \mathrm{kgK} \\ \mathrm{D} & \text { Diameter, } \mathrm{m} \\ \mathrm{ETHP} & \text { Evacuated tube heat pipe } \\ \dot{E n} & \text { Energy rate, W } \\ \dot{E x} & \text { Exergy rate, W } \\ \mathrm{h} & \text { Heat transfer coefficient, W/mK } \\ \mathrm{I} & \text { Solar radiation, W/m }{ }^{2} \\ \mathrm{~L} & \text { Length, } \mathrm{m} \\ \dot{m} & \text { Mass flow, kg/s } \\ \mathrm{Nu} & \text { Nusselt number } \\ \mathrm{Pr} & \text { Prandtl number } \\ \mathrm{Ra} & \text { Rayleigh number } \\ \mathrm{SI} & \text { Sustainability Index } \\ \mathrm{T} & \text { Temperature, K }\end{array}$

\section{Greek Letters}

$\rho_{\text {ref }}$

Solar reflectance

$\rho_{\text {rec }} \quad$ Solar absorbtance

$\varepsilon_{\text {rec }} \quad$ Solar emittance

$\eta \quad$ Efficiency

\section{References:}

[1] S.G. Hamed, " The share of cooling electricity in global warming: Estimation of the loop gain for the positive feedback" $\quad$ Energy, 179, 747-761. https://doi.org/10.1016/j.energy.2019.04.170

[2] B. Du, P.D. Lund, J. Wang, "Combining CFD and artificial neural network techniques to predict the thermal performance of all-glass straight evacuated tube solar collector," Energy, 220, 119713, https://doi.org/10.1016/j.energy.2020.119713

[3] B. Pourkafi, B.M. Ziapour, A.R. Miroliaei, "Numerical study of the transparent cover effects with miscellaneous shapes on the parabolic trough solar collector performance," International Journal of Thermodynamics, 23 (1), 1-23, https://doi.org/10.5541/ijot.601417

[4] A. Maraj, A. Londo, A. Gebremedhin, C. Firat, "Energy performance analysis of a forced circulation solar water heating system equipped with a heat pipe evacuated tube collector under the Mediterranean climate conditions," Renewable Energy, 140, 874-883, https://doi.org/10.1016/j.renene.2019.03.109

[5] K. Chopra, V.V. Tyagi, A.K. Pandey, Z. Ma, H. Ren, "Energy, exergy, enviroeconomic \& exergoeconomic (4E) assessment of thermal energy storage assisted solar 
water heating system: Experimental \& theoretical approach," Journal of Energy Storage, 35, 102232, https://doi.org/10.1016/j.est.2021.102232

[6] M. Eltaweel, A.A. Abdel-Rehim, A.A.A. Attia, "Energetic and exergetic analysis of a heat pipe evacuated tube solar collector using MWCNT/water nanofluid," Case Studies in Thermal Engineering, 22, 100743, https://doi.org/10.1016/j.csite.2020.100743

[7] Chr. Lamnatou, E. Papanicolaou, V. Belessiotis, N. Kyriakis, "Experimental investigation and thermodynamic performance analysis of a solar dryer using an evacuated-tube air collector," Applied Energy, 94, 232-243,

https://doi.org/10.1016/j.apenergy.2012.01.025

[8] N. Modi, B. Pandya, "Integration of Evacuated Solar Collectors with an Adsorptive Ice Maker for Hot Climate Region," Energy and Built Envrionment, in press, https://doi.org/10.1016/j.enbenv.2021.01.001

[9] G. Saxena, M.K. Gaur, “ Energy, exergy and economic analysis of evacuated tube solar water heating system integrated with heat exchanger," Materials today: Proceedings, 28 (4), 2452-2462, https://doi.org/10.1016/j.matpr.2020.04.793

[10] A.V. Kumar, T.V. Arjunan, D. Seenivasan, R.Venkatramanan, S. Vijayan, " Thermal performance of an evacuated tube solar collector with inserted baffles for air heating applications," Solar Energy, 215, 131-143, https://doi.org/10.1016/j.solener.2020.12.037

[11] H. Olfian, S.S.M. Ajarostaghi, M. Farhadi, A. Ramiar, "Melting and solidification processes of phase change material in evacuated tube solar collector with U-shaped spirally corrugated tube," Applied Thermal Engineering, 182 , 116149 , https://doi.org/10.1016/j.applthermaleng.2020.116149

[12] A. Ozsoy, V. Corumlu, "Thermal performance of a thermosyphon heat pipe evacuated tube solar collector using silver-water nanofluid for commercial applications," Renewable Energy, 122, 26-34, https://doi.org/10.1016/j.renene.2018.01.031

[13] V. Corumlu, A. Ozsoy, M. Ozturk, "Thermodynamic studies of a novel heat pipe evacuated tube solar collectors based integrated process for hydrogen production," International Journal of Hydrogen Energy, $43 \quad$ (2), 1060-1070, https://doi.org/10.1016/j.ijhydene.2017.10.107

[14] O. Kizilkan, S. Khanmohammadi, H. Yamaguchi, "Two-objective optimization of a transcritical carbon dioxide based Rankine cycle integrated with evacuated tube solar collector for power and heat generation", Applied Thermal Engineering, 182, 116079, https://doi.org/10.1016/j.applthermaleng.2020.116079

[15] M. Ozturk, I. Dincer, "Thermodynamic analysis of a solar-based multi-generation system with hydrogen production," Applied Thermal Engineering, 51 (1-2), 1235-1244, https://doi.org/10.1016/j.applthermaleng.2012.11.042

[16] A.Y. Faraji, A. Date, R. Singh, A. Akbarzadeh, "Baseload Thermoelectric Power Generation Using Evacuated Tube Solar Collector and Water Storage Tank," Energy
Procedia

57 ,

$2112-2120$ https://doi.org/10.1016/j.egypro.2014.10.178

[17] R. K. Kumar, N.V.V.K. Chaitanya, N.S. Kumar, "Solar thermal energy technologies and its applications for process heating and power generation - A review," Journal of Cleaner Production, 282, 125296, https://doi.org/10.1016/j.jclepro.2020.125296

[18] D.S. Ayou, G. Zaragoza, A. Coronas, "Small-scale renewable polygeneration system for off-grid applications: Desalination, power generation and space cooling," Applied Thermal Engineering, 182, 116112, https://doi.org/10.1016/j.applthermaleng.2020.116112

[19] J.Z. Alvi, Y. Feng, Q. Wang, M. Imran, G. Pei, "Effect of working fluids on the performance of phase change material storage based direct vapor generation solar organic Rankine cycle system," Energy Reports, 7, 348361, https://doi.org/10.1016/j.egyr.2020.12.040

[20] O. Kizilkan, H. Yamaguchi, "Feasibility research on the novel experimental solar-assisted $\mathrm{CO}_{2}$ based Rankine cycle integrated with absorption refrigeration," Energy Conversion and Management, 205, 112390, https://doi.org/10.1016/j.enconman.2019.112390

[21] O. Kizilkan, S. Khanmohammadi, M. Saadat-Targhi, "Solar based $\mathrm{CO} 2$ power cycle employing thermoelectric generator and absorption refrigeration: Thermodynamic assessment and multi-objective optimization," Energy Conversion and Management, 200, 112072, https://doi.org/10.1016/j.enconman.2019.112072

[22] H. Caliskan, "Energy, exergy, environmental, enviroeconomic, exergoenvironmental (EXEN) and exergoenviroeconomic (EXENEC) analyses of solar collectors," Renewable and Sustainable Energy Reviews, 69, 488-492, https://doi.org/10.1016/j.rser.2016.11.203

[23] O.A. López-Núñez, J.A. Alfaro-Ayala, J.J. RamírezMinguela, J.M. Belman-Flores, O.A. Jaramillo, "Optimization of a Linear Fresnel Reflector Applying Computational Fluid Dynamics, Entropy Generation Rate and Evolutionary Programming," Renewable Energy, 152, 698-712, https://doi.org/10.1016/j.renene.2020.01.105

[24] O.A. López-Núñez, J.A. Alfaro-Ayala, O.A. Jaramillo, J.J. Ramírez-Minguela, J.C. Castro, C.E. DamianAscencio, S. Cano-Andrade., "A numerical analysis of the energy and entropy generation rate in a Linear Fresnel Reflector using computational fluid dynamics," Renewable Energy, 146, 1083-1100, https://doi.org/10.1016/j.renene.2019.06.144

[25] D. Aydin, Z. Utlu, O. Kincay, "Thermal performance analysis of a solar energy sourced latent heat storage," Renewable and Sustainable Energy Reviews, 50, 12131225, https://doi.org/10.1016/j.rser.2015.04.195

[26] S. Abo-Elfadl, H. Hassan, M.F. El-Dosoky, "Energy and exergy assessment of integrating reflectors on thermal energy storage of evacuated tube solar collectorheat pipe system," Solar Energy, 209, 470-484, https://doi.org/10.1016/j.solener.2020.09.009

[27] H. Caliskan, I. Dincer, A. Hepbasli, "Exergoeconomic and environmental impact analyses of a renewable energy based hydrogen production system," 
International Journal of Hydrogen Energy, 38(14), 61046111, https://doi.org/10.1016/j.ijhydene.2013.01.069

[28] A. Fudholi, M. Zohri, N.S.B. Rukman, N.S. Nazri, M. Mustapha, A.H. Yen, M. Mohammad, K. Sopian, "Exergy and sustainability index of photovoltaic thermal (PVT) air collector: A theoretical and experimental study," Renewable and Sustainable Energy Reviews, 100, 44-51, https://doi.org/10.1016/j.rser.2018.10.019

[29] O.A. López-Núñez, J.A. Alfaro-Ayala, O.A. Jaramillo, J.J. Ramírez-Minguela, J.C. Castro, C.E. DamianAscencio, S. Cano-Andrade, "A numerical analysis of the energy and entropy generation rate in a Linear Fresnel Reflector using computational fluid dynamics," Renewable Energy, 146, 1083-1100, https://doi.org/10.1016/j.renene.2019.06.144

[30] M. Faizal, R. Saidur, S. Mekhilef, A. Hepbasli, L.M. Mahbubul, "Energy, economic, and environmental analysis of a flat-plate solar collector operated with $\mathrm{SiO} 2$ nanofluid," Clean Technologies and Environmental Policy, 17, 1457-1473, https://doi.org/10.1007/s10098014-0870-0

[31] A. K. Singh, Samsher, "Analytical study of evacuated annulus tube collector assisted solar desaltification system: A review," Solar Energy, 207, 1404-1426, https://doi.org/10.1016/j.solener.2020.07.097

[32] M. Faizal, R. Saidur, S. Mekhilef, M.A. Alim, “Energy, economic and environmental analysis of metal oxides nanofluid for flat-plate solar collector," Energy Converison and Management, 76, 162-168, https://doi.org/10.1016/j.enconman.2013.07.038
[33] M.S. Yousef, H. Hassan, H. Sekiguchi, "Energy, exergy, economic and enviroeconomic (4E) analyses of solar distillation system using different absorbing materials," Applied Thermal Engineering, 150, 30-41, https://doi.org/10.1016/j.applthermaleng.2019.01.005

[34] U. Akbulut, Z. Utlu, O. Kincay, "Exergy, exergoenvironmental and exergoeconomic evaluation of a heat pump-integrated wall heating system," Energy, 107 , 502-522, https://doi.org/10.1016/j.energy.2016.04.050

[35] K.G. Mofrad, S. Zandi, G. Salehi, M.H.K. Manesh, "Comparative 4E and advanced exergy analyses and multi-objective optimization of refrigeration cycles with a heat recovery system," International Journal of Thermodynamics, 23(4), https://doi.org/10.5541/ijot.749471

[36] U. Akbulut, Z. Utlu, O. Kincay, "Exergoenvironmental and exergoeconomic analyses of a vertical type ground source heat pump integrated wall cooling system," Applied Thermal Engineering, 102, 904-921, https://doi.org/10.1016/j.applthermaleng.2016.03.178

[37] I. Singh, S. Vardhan, "Experimental investigation of an evacuated tube collector solar air heater with helical inserts," Renewable Energy, 163, 1963-1972, https://doi.org/10.1016/j.renene.2020.10.114 